\title{
モルタルの透気性に及ぼす細骨材量の影響
}

\section{INFLUENCE OF FINE AGGREGATE CONCENTRATION ON AIR PERMEABILITY OF CEMENT MORTAR}

\author{
田中亨二*1, 国田洋行*2, 橋田 浩*3 \\ Kyoji TANAKA, Hiroyuki KUNITA and Hiroshi HASHIDA
}

\begin{abstract}
Influence of fine aggregate concentration on air permeability of cement mortar is experimentally and analytically studied. The air permeability of cement mortar specimens of various fine aggregate concentrations were first measured. It was found out that an increase of concentration slightly reduced air permeability of the mortars in the range of lower concentration and, on the contrary, noticeably increased it in the higher concentration range. This results suggest that air permeability affected by the existence of boundary layers, which are considered to be highly porous, around the fine aggregates. Then, the two dimentional model composed of three components such as cement paste, fine aggregate and boundary layer was proposed, and the air permeability were calculated for mortars of various fine aggregate concentrations. Finally, the influence of concentration on air permeability of mortars was quantitatively discussed on the basis of the measured and calculated results.
\end{abstract}

Keywords: Air permeability, Cement mortar, Fine aggregate concentration, Pore structure, Boundary layer, Two dimentional model 透気性、セメントモルタル、細骨材量、細孔構造、境界層、2 次元モデル

1 はじめに

セメントパーストは多孔体であり、微量ながらも気体を透過させ る性質をもつ。一方、通常の粗骨材、細骨材はそれに比べると、透 気性ははるかに小さい。従って、骨材とセメントペーストの複合体 であるコンクリートやモルタルでは、基本的には透気性はパースト と骨材の割合により決定されると考えることができる。

すなわち、骨材量の増加はセメントペースト容積を相対的に低下 させるため、透気しうるペースト部分の容䄼を减少させると考えら れ、透気性を低下させると推定される。しかし一方で、骨材近傍お よび界面には組織が粗な領域が存在するといわれており ${ }^{122) 、 そ の ~}$ 考えに従えば、骨材量の增加は透気しやすい容積を增加させること になるため、逆に透気性を增加させるとも考えられる。両者相反す る影響が類推されるのである。このことに関して現状では、透気性 に対する骨材量の影響に関寸る研究が十分なされておらず、明確な 結論は得られてはいない。

透気性の問題は前報 ${ }^{3)}$ でも述べたとおり、強度や乾煤収縮といっ た実用面に直結する項目ではないため、上もすれば看過されやすい が、コンクリートの㓦久性の分野、特に最近では、コンクリートを 下地として施工される各種仕上归材の分野で、それらの久陥発生に 影響を与える重要な要因として、これらの知見が強く要望されるよ うになってきている。

\footnotetext{
*1 束京厂.棠大学:建築物理研究センター 教授・工博

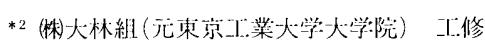

*3 清水建设侏技術研究所 I. I修
}

セメント硬化体の透気性は、基本的には硬化セメントペーストの 細孔量と分布、および環境湿度に応じた細孔内部の水分状態により 決定される。しかしモルタルやコンクリートでは、必ず骨材との共 存状態で使用される。そうすると骨材の量が、特に骨材とペースト の界面の量や性状がどのような影響老及ぼすのかが、きわめて重要 になる。本研究ではこの点に着目し、研究の第一段階としてモルタ ルを例とし、骨材量の透気性に及ぼす影響を明かにすることを目的 とする。

既往の研究についてであるが、透水性については骨材の影響が検 討されており、一般に骨材量の増加は透水性を単純に增加させる と報告されている ${ }^{4,5)}$ 。また興味染い結果として、Houst 等 $^{6)}$ はモ ルタルの拡散性について骨材量の影響を拡散保数との関保で調バ、 ペーストに小量の骨材を混入する範囲では、拡散係数は堿少するが、 多量の骨材量の範囲では逆に拡散係数は増加する傾向を明かにして いる。しかしながら透気性の観点からの骨材量の影響に関寸る研究 は、国内外を問わず、筆者等の知る範囲ではほとんどない。

\section{2 圾験の概要 \\ 2. 1 試験体の種類}

試験体は豊浦標準砂を用いたモルタルである。砂量は、砂とセメ ントペーストの容積比率（S/P）で 0.45、0.70、1.22、および砂を入
Prof., Structural Engineering Research Center, Tokyo Institute of Technology, Dr. Eng.

Ohbayashi Corporation, M. Eng.

Institute of Technology, Shimizu Corporation, M. Eng. 
れないもの（セメントペーストのみで $\mathrm{S} / \mathrm{P}=0$ ) の 4 水準とした。ま たこれらモルタルのペースト部分の水セメント比は 45、60、75\% の3 水準とした。表 1 に本研究に用いたモルタルの調合を示寸。な おこの中で、砂量の最も多い（ $\mathrm{S} / \mathrm{P}=1.22 ）$ の場合は充填性が悪く空 気量も多くなっており、通常施工されるモルタルの物性からは多少 灕れているが、砂量の影響を検討寸る目的から、本研究では、あえ て試験体に加えている。

\section{2 試験体の作成}

セメントペーストおよびモルタルは、直径 $180 \mathrm{~mm}$ 高さ $70 \mathrm{~mm}$ の 塩化ビニル製円筒型枠に打ち込み、1 日封かん養生後脱型し、8週 間水中養生を行った。その後直径 $30 \mathrm{~mm}$ のコアを採取し、コンクリ 一トカッターで、ブリージングの影響の少ない中央部分から厚さ 3 $\sim 10 \mathrm{~mm}$ の試験体を切り出した。

\section{3 透気試験}

透気量は前報 ${ }^{3)}$ で示したとおり、内部水分の影響を強く受ける。 そのため、ここでは恒温恒湿室 $\left(20 \pm 2{ }^{\circ} \mathrm{C}, 75 \pm 10 \%\right.$ R.H. $)$ 内に、 重量測定によりその值が一定となるまで放置した。重量が安定する までにはほぼ一ヶ月要したが、さらにもう一ヶ月、恒温恒湿室内に 靜置し十分に安定させた後で、各種測定を行った。

透気量の測定には、図 1 に示寸透気試験装置を用いた。試験体が 比較的薄いため、測定中、空気圧による曲げひび割れが生じるおそ れがある。その予防のため、多数の孔の開けられた真鍮製の背板を 補強として使用した。

試験片の側面はエポキシ樹脂により完全にシールし、側面からの 空気の流出入を防いだ。測定は負荷圧力 $0.05 \mathrm{MPa} \sim 0.3 \mathrm{MPa}$ の範囲 で行い、試験体内部を透過した空気の流量が定常となったことを確 認した上で、水上置換法により透過空気量を測定した。なお試験体 数は原則として 2 個ずつとしたが、測定に失敗することもあり、そ の場合には試験体を追加した。

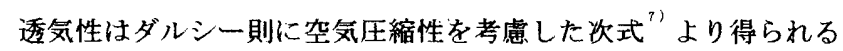
透気係数で評価した。

$$
\begin{gathered}
\mathrm{k}=2 \mathrm{~L} \mu \mathrm{P}_{2} \mathrm{Q} /\left(\mathrm{P}_{1}{ }^{2}-\mathrm{P}_{2}{ }^{2}\right) \mathrm{A} \\
\text { ここに } \quad \mathrm{Q}: \text { 透気量、 } \mathrm{m}^{3} / \mathrm{sec} \\
\mathrm{k}: \text { 透気倸数、 } \mathrm{m}^{2} .
\end{gathered}
$$

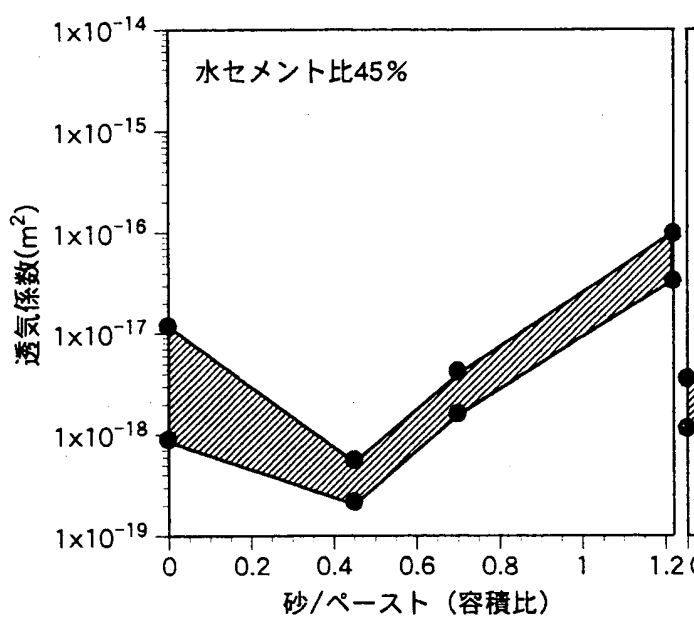

図 2 細骨材量と透気係数の関係

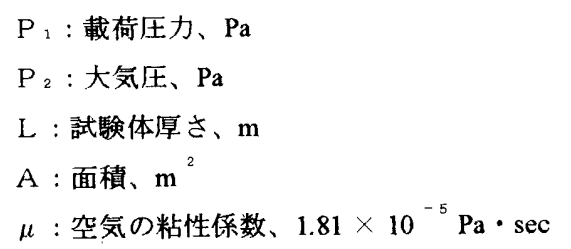

\section{3 湘定結果}

図 2 に透過気保数と細骨材量との関俰を示寸。砂/ペースト比 (S/P) がゼロの位置はセメントペーストのみであることを意味す

\begin{tabular}{|c|c|c|c|c|c|c|}
\hline 試験体の種類 & $\begin{array}{l}\mathrm{W} / \mathrm{C} \\
\text { 重量\% }\end{array}$ & $\begin{array}{l}\mathrm{S} / \mathrm{P} \\
\text { 容積比 }\end{array}$ & $\begin{array}{c}\text { セメント }(\mathrm{C}) * 2 \\
\mathrm{~g}\end{array}$ & $\begin{array}{r}\text { 水 }(W) \\
g\end{array}$ & $\begin{array}{c}\text { 砂 (S) } \\
\mathrm{g}\end{array}$ & $\begin{array}{c}\text { 空気量 } \\
\%\end{array}$ \\
\hline $\begin{array}{l}\text { セメント } \\
\text { ベースト }\end{array}$ & $\begin{array}{l}45 \\
60 \\
75\end{array}$ & $\begin{array}{l}0 \\
0 \\
0\end{array}$ & $\begin{array}{l}1823 \\
1523 \\
1310\end{array}$ & $\begin{array}{l}820 \\
914 \\
983\end{array}$ & $\begin{array}{l}0 \\
0 \\
0\end{array}$ & $\begin{array}{l}0.2 \\
0.1 \\
0.4\end{array}$ \\
\hline $\begin{array}{l}\text { 豊浦標準眇*' } \\
\text { モルタル }\end{array}$ & $\begin{array}{l}45 \\
45 \\
45 \\
60 \\
60 \\
60 \\
75 \\
75 \\
75\end{array}$ & $\begin{array}{l}0.45 \\
0.70 \\
1.22 \\
0.45 \\
0.70 \\
1.22 \\
0.45 \\
0.70 \\
1.22\end{array}$ & $\begin{array}{r}1257 \\
1071 \\
822 \\
1050 \\
896 \\
686 \\
903 \\
770 \\
589\end{array}$ & $\begin{array}{l}566 \\
490 \\
370 \\
630 \\
538 \\
412 \\
678 \\
578 \\
442\end{array}$ & $\begin{array}{l}1189 \\
1576 \\
2103 \\
1189 \\
1576 \\
2103 \\
1189 \\
1576 \\
2103\end{array}$ & $\begin{array}{l}1.0 \\
3.8 \\
7.9 \\
0.4 \\
0.2 \\
7.2 \\
0.8 \\
0.2 \\
8.0\end{array}$ \\
\hline
\end{tabular}
る。ペースト部分の水セメント比により多少の違いはあるが、砂の 表 1 試験体および調合

*1山口県豊浦産(絶乾比重 2.72、吸水率0.54)

*2 普通ポルトランドセメント（比重 3.16）

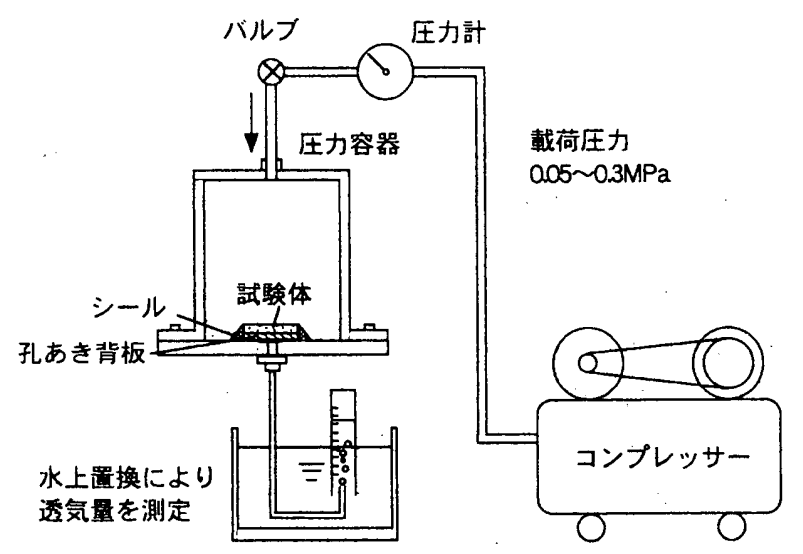

図 1 透気試験の概要

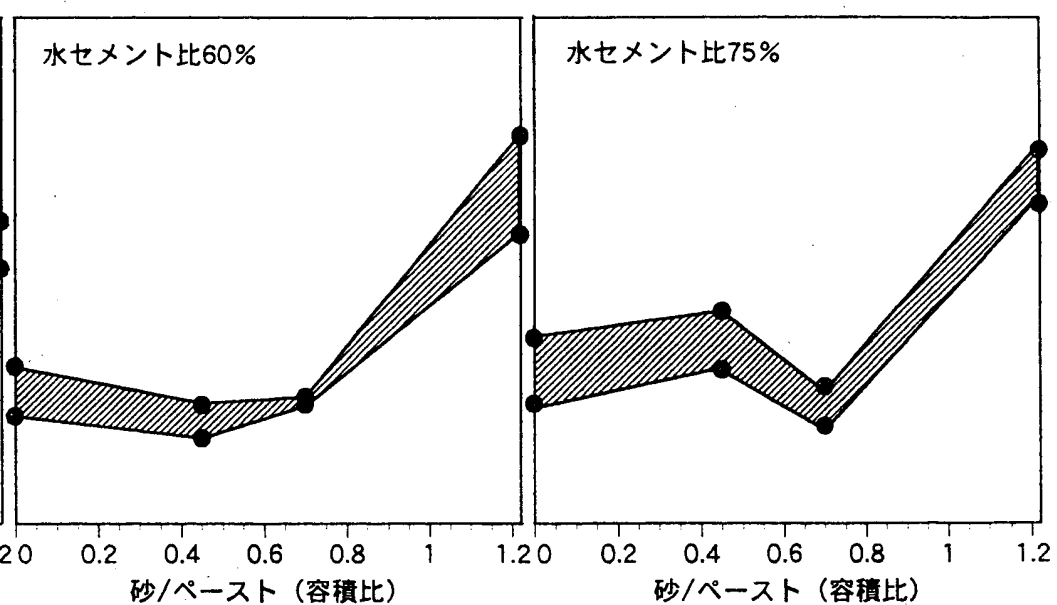

砂/ペースト（容嫧比） 
混入は一時的に透気係数を低下させる。しかし、さらなる増加は逆 に透気保数を大きくさせる。すなわち適当な砂量の時に透気性は極 小になる㑯向がうかがえる。ただし透気係数を極小とする砂ペース 卜比は、水セメント比により異なり、水セメント比が大きくなるに したがって、その比は增加する傾向がみられる。

\section{4 考察}

4. 1 モルタルの細れ構造におよぼす砂量の影響

（1） 水銀圧入法による細孔容積測定

ここでの試験体は、湿度 $75 \%$ R H の環境下に長期間保管されて おり、細孔の内部には雾囲気湿度と平衡となる水分が含まれている。 そのため細孔容積の測定は、既報 ${ }^{8)}$ で述べた、水分を含む状態での 細孔構造を調べるための、水銀圧入法に工夫を加えた方法によった。 測定方法の特徽は、その手順の概略を図 3 に示寸ように、水分散逸 を少なくするために通常の測定で行われるDドライ処理を割愛して いること、また水銀圧入前の減圧のレベルを $950 \mu \mathrm{mHg}$ 程度に弱 めていること、測定途中でわずかではあるが、散晩する水分量につ いては、その量を測定して補正する点にある。なお測定にはマイク ロメリテックス社製ポロシメーター9310 型を使用した。

\section{(2) 細孔容糟分布}

図 4 に測定より得られたセメントペースト、モルタルの細孔容積 分布を示す。砂を混入していないセメントペーストだけの場合は、 水セメント比にかかかからず、0.01 $\mu \mathrm{m}$ 前後の細孔径が卓越して存 在している。砂を混入した場合、砂量の増加にともなってそのピー クの高さが低下し、大きな細孔径領域の量も增加寸る。この傾向は、 水セメント比が大きくなるに従って顕著となる。一方砂量が極端に 多い試験体（S/P:1.22）の場合は、特定の細孔径に極値をもたず、 広い領域にわたり粗な細孔構造をもつ。

\section{2 モルタルの透気モデルを用いた透気性の評俩}

(1) 計算モデル

セメントペースト、細骨材より構成され、さらにそれに骨材界面 近傍の組織の粗な領域を考慮した、一辺の長さが $100 \mu \mathrm{m}$ の 2 次 元格子状細管モデルに置換した。その単位断面は図 5 に示すように、 そのサイズを細骨材の最大粒径の 15 倍程度とし、 $3 \mathrm{~mm} \times 3 \mathrm{~mm}$ の 断面積を 900(30×30)分割したものとした。また計算モデルは、計 算量低減化はかるため、この単位断面部分が試験体の断面積と等し くなるまで絽り返され、断面が構成されるものとした。

(2) 細孔のモデル化

モルタルの細孔は、それらが連続した時、空気の通り道となる。 この連続する細孔をすべてハーダン・ポアズイユの法則が成立する 細管で置き換える。この細管を流れる流体の定常流の時の流量は、 次式で与えられる。

$$
\begin{aligned}
\mathrm{Q}=\pi \Delta \mathrm{Pd}^{4} / & 128 \mu \mathrm{l} \\
\text { ここに } \quad \mathrm{Q}: & : \text { 流量、 } \mathrm{m}^{3} / \mathrm{s} \mathrm{e} \mathrm{c} \\
\Delta \mathrm{P} & : \text { 压力差、 } \mathrm{P} \mathrm{a} \\
\mathrm{d} & : \text { 細管の直径、 } \mathrm{m} \\
1 & : \text { 細管の長さ、 } \mathrm{m} \\
\mu & : \text { 粘性係数、 } \mathrm{P} \mathrm{a} \cdot \mathrm{s} \mathrm{e} \mathrm{c}
\end{aligned}
$$

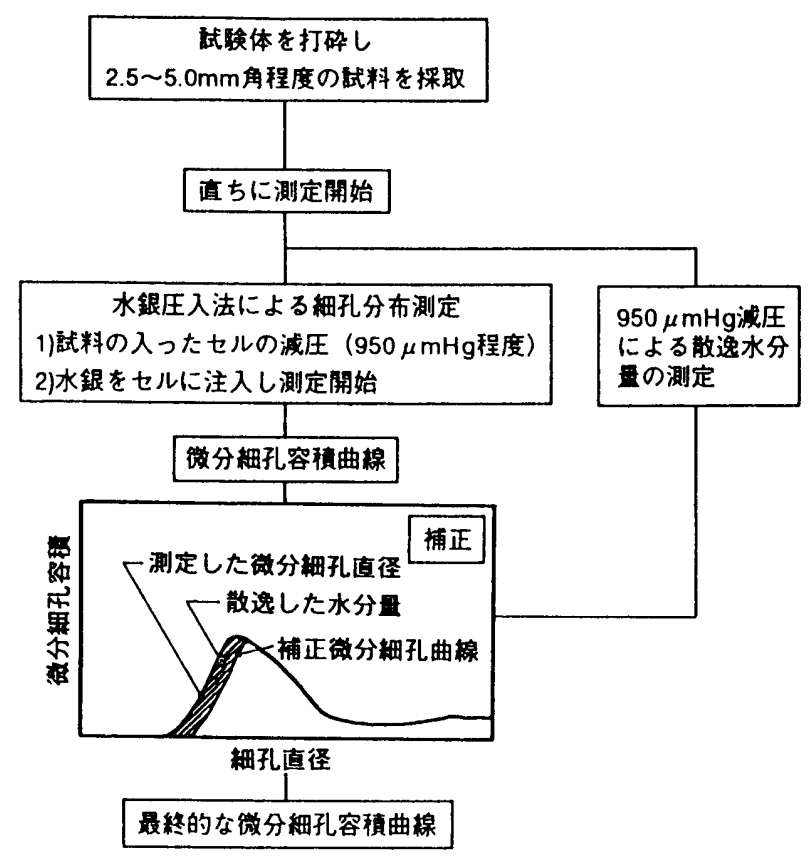

図 3 水分を含む状態での細孔構造測定方法

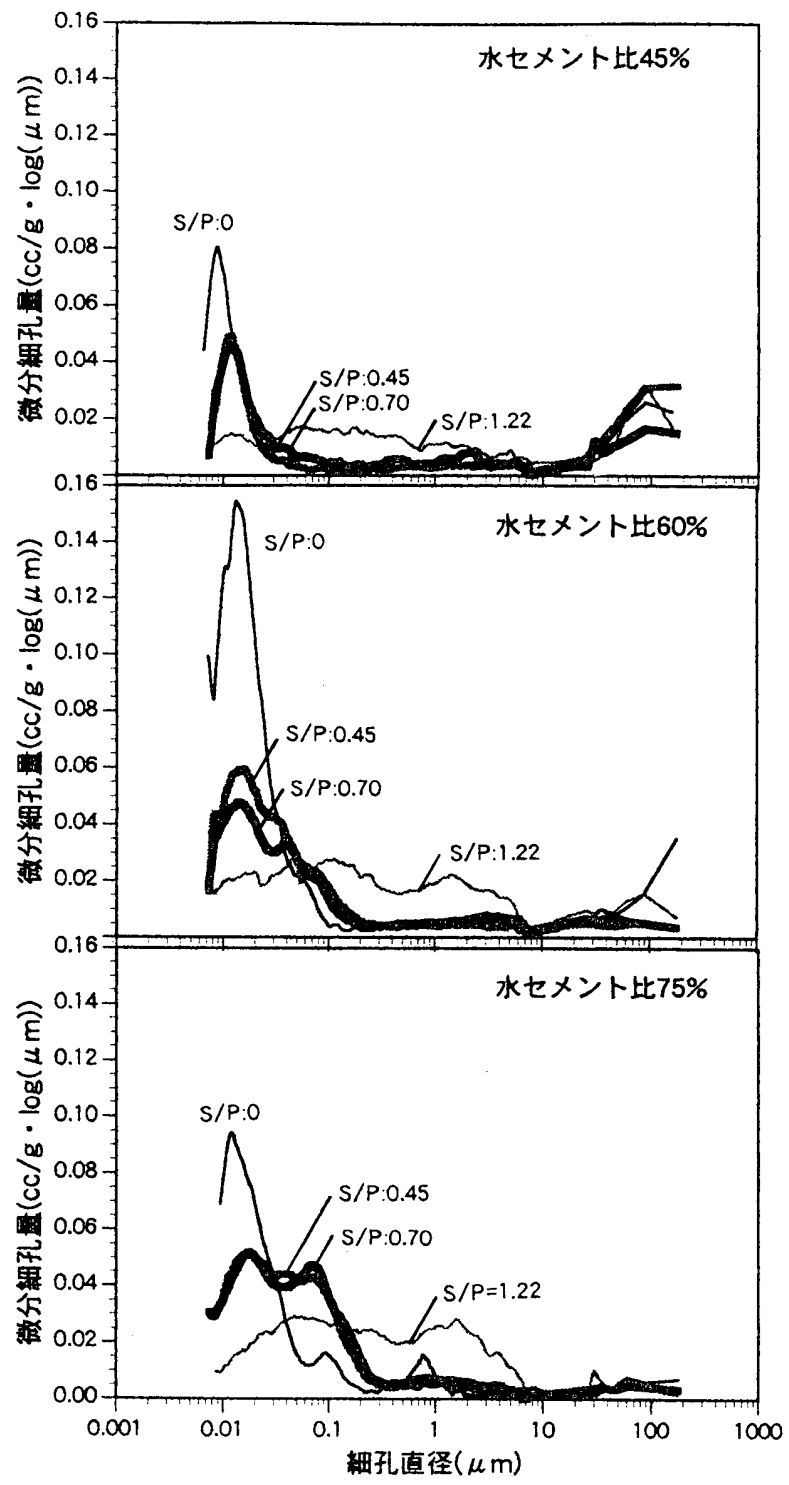

図 4 セメントペースト、モルタルの細孔容積分布 
細孔測定結果では、モルタル中には非常に小さな細孔も存在する が、文献”によれば、透気に関与する細孔は約 $50 \mathrm{~nm}$ より大きな直 径のものであるといわれており、ここでは $50 \mathrm{~nm}$ より大きい空隙に ついて検討した。

一方最大空隙径についてであるが、大きい径のものは独立してお り、透気の観点からは不連続状態にあることが多い。そのため、ど の程度の径から連続した空隙として取り扱うことができるかが問題 となる。この点について、Dullien ${ }^{10)}$ は水銀圧入法により得られる 累積細孔曲線において、図 6 に示すように急激な增加を示す点が、 いわゆる細孔のくびれ部分に水銀が流入し始める点であり、ここか ら測定される空隙が連続した細孔であると考えることができると述 べている。本研究でもこの考えに基づき、各試倹体について調べた ところ、その值が累糟細孔曲線の微分值、 $\mathrm{d}$ V $/ \mathrm{d} \log \mathrm{D}$,でほぼ 0.005 を越えると、比較的安定して細孔量が增加するため、この点を透気 に関与寸る最大直径判定基準とし、この細孔直径以下のものを連続 細孔として判断した。

つぎに骨材界面近傍の細孔構造についてであるが、セメントパー ストと細骨材の境界は、完全にセメントペーストが細骨材に密着し ていないことが多いといわれている。例えば、骨材近傍のペースト 部分には、水酸化カルシウムの水和物が多く形成され、大きい細孔 を多く有する、いわゆる遷移帯と呼ばれる領域が形成される ${ }^{1{ }^{12}}$ 、 あるいはペーストに含まれる余剩水は、内部の水移動により、結果 として骨材周囲、特にその下側に粗な組織を作る ${ }^{12)}$ 等のためであ る。従って透気性を評価する場合、この骨材近傍の粗となる細孔構 造の存在を考慮することが重要である。

ところで、ポロシメーターによるモルタル部分の細孔構造の測定 では、この骨材近傍の粗となる細孔を含んでいる。従ってモルタル 内部の骨材近傍の細孔構造は、図 7 に示すように、モルタルの細孔 量からセメントペースト部分の細孔量を差し引いた、残りの部分と

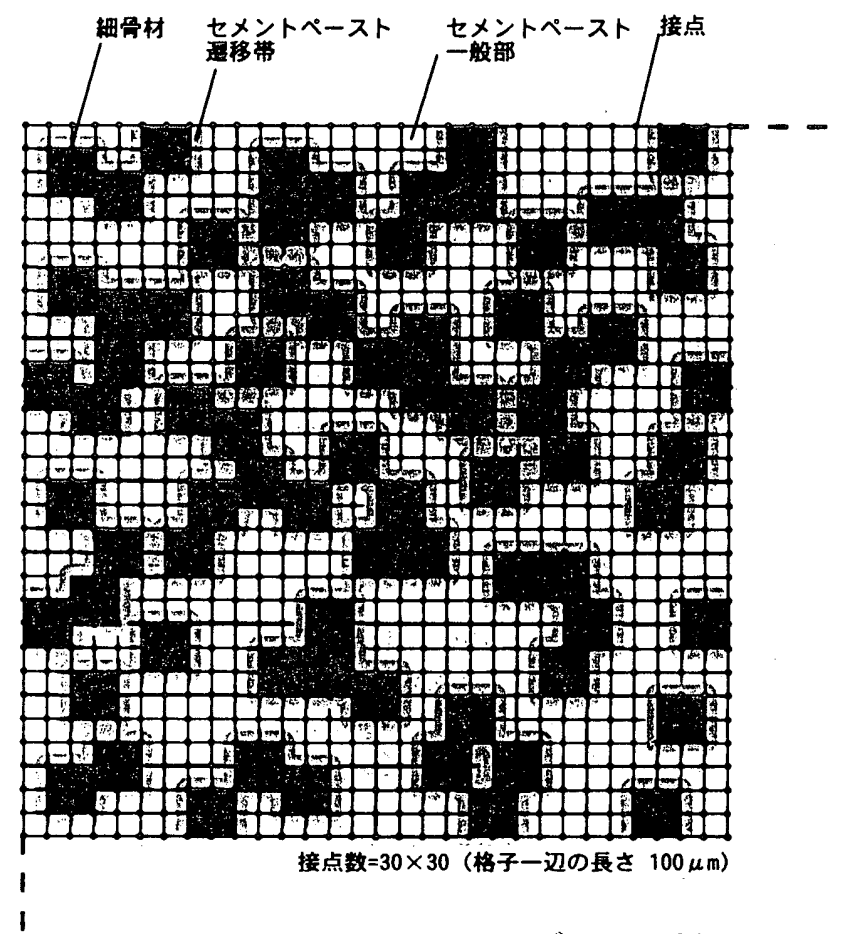

図 5 単位断面 $(3 \mathrm{~mm} \times 3 \mathrm{~mm})$ のモデル化の例
して考えることができる。すなわち、モルタルの累積細孔曲線とぺ 一スト部分の累糟細孔曲線の差として得られる。この考え方に基づ き得た、差の部分を微分表現で表し、図8に示す。これによると、 砂量の多い砂ペースト比が 1.22 の試験体を除けば、骨材近傍の細 孔構造は約 $0.02 \mu \mathrm{m}$ から $0.5 \mu \mathrm{m}$ 程度までのものがかなりを占め ると考えられる。また、砂ペースト比が 1.22 の場合は、全体とし てブロードになり、その細孔径範曲も広がり、最大径 $10 \mu \mathrm{m}$ 近く にまで及ぶと考えられる。

またその厚さは、一般に遷移帯では骨材から50 $\mu \mathrm{m}$ 程度といわ れており 、ここでのモデルでは、細骨材周りを上述の粗な細孔 構造をもつ組織が $50 \mu \mathrm{m}$ の厚さで取り卷いていると仮定した。

なお透気計算では、各格子を構成する連続細管 (50nm から前述 の最大直径までの範囲のもの）を、計算の簡素化をはかるため 4 分 割し、その各々の平均值の細管で構成される透気モデルとした。す なわち、4 分割した領域での細孔量からその平均径に置换した時の 本数を求め、それら 4 種類の細管が図 9 に示寸ように、並列して細 管束を形成し、接点で連結・合流するものである。

またモルタル各構成要素の細孔は、次によりその具体的な数值を 与えた。

・ペースト部分

ペースト部分は、測定より得られた細孔容積分布を用いる。

・細骨材部分

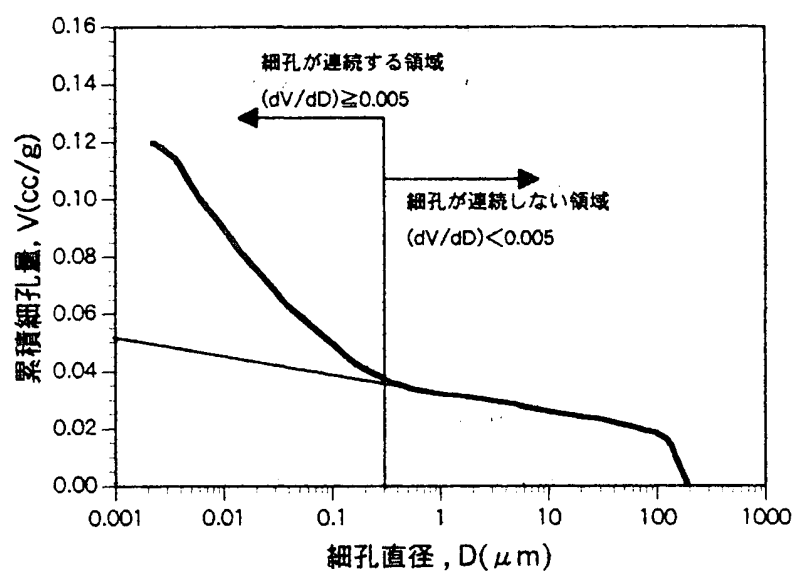

図 6 連続細孔径の最大值の判定

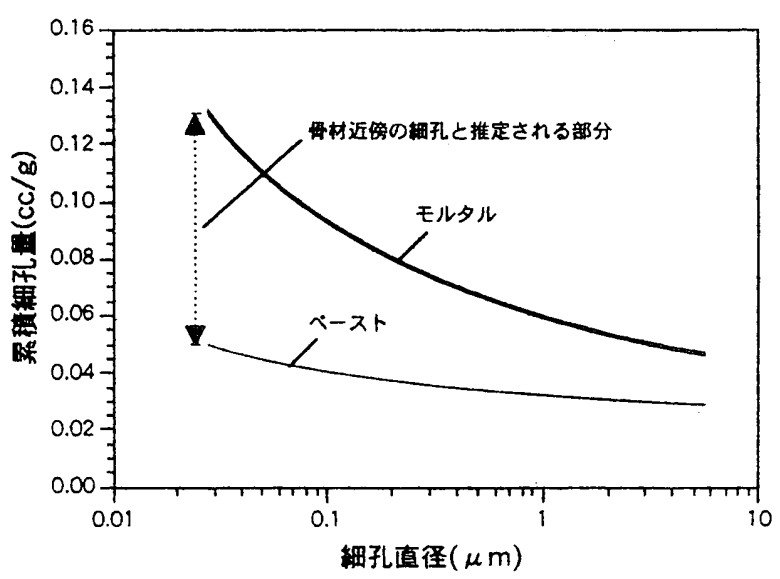

図 7 骨材近傍の細孔構造推定の概念図 
ここで用いた骨材は、豊浦標準砂であり、ペーストに比べてはる かに維密であり、透気はほとんどしないものと考えた。なお細骨材 の粒度分布は図 1 ○に示すとおり、125 $\mu \mathrm{m} \sim 225 \mu \mathrm{m}$ の範囲の ものがほとんどであるため、モデルではその簡素化をはかり、その 細骨材籸径を $200 \mu \mathrm{m}$ で代表させた。

- 骨材界面近傍

骨材界面近傍の領域（遷移帯）に対しては図 8 の細孔容積分布を 用いた。

- 気泡

試験体には、表 1 に示すとおり空気量の大きいものもあり、その 影響は無視できないものと思われる。ただし一般に気泡は球形で独

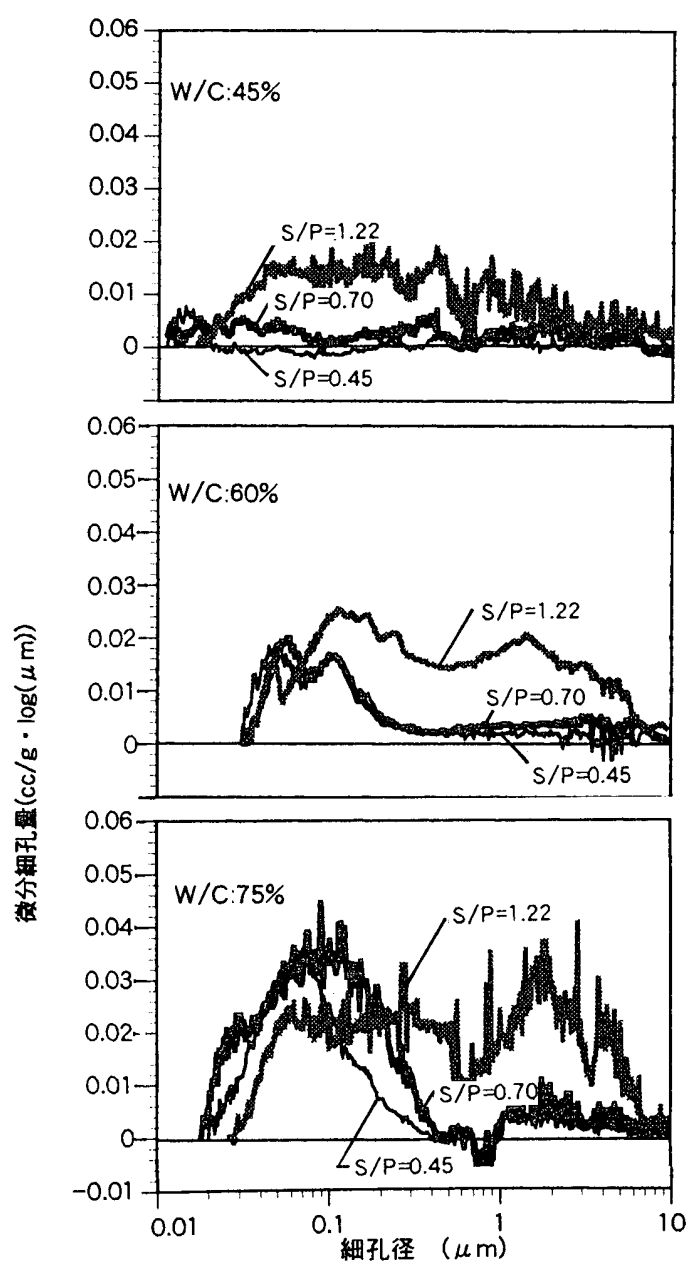

図 8 推定される骨材近傍の細孔構造

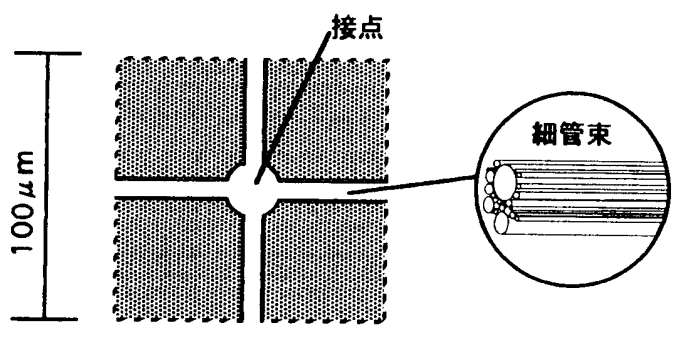

図 9 各格子の細孔モデル

(4 種類の細管の束として単純化)
立しており、その数も水銀圧入法で測定される細孔容積に比べて非 常に少ない。モれ防え、気泡は連結した空気の通り道として影響を およぼすと考えるよりは、試験体の実質的なマトリックス部分を減 らす效果として考えるほうが妥当であると思われる。そのためここ では、空気量をその分だけ試験体の厚さが減じたものとして取り扱 った。

（3）計算方法

透気の計算は以下の手順によった。

(1)セメントペースト、遷移帯を構成する細管束の各々の透気倸数を ハーダンポアズイコ則によって求める。

(2)細骨材の位圈を乱数により決定する。

(3)接点を中心とする単位領域の透気係数を決定する。この時セメン トペースト部分、遷移带部分は各々の透気係数を、細骨材は0を与 える。

(4)質量保存則から各接点の流量 Qの総和は○となるので、図 11 に に示す $\mathrm{i}$ 接点では次式が成り立つ。

$\Sigma Q=\Sigma \frac{(k i-k(j))}{2}(P i-P(j))=0$

ここで $\mathrm{k}$ は透気保数、 $\mathrm{P}$ は圧力、(j)は $\mathrm{i}$ 点まわりのすべての接点

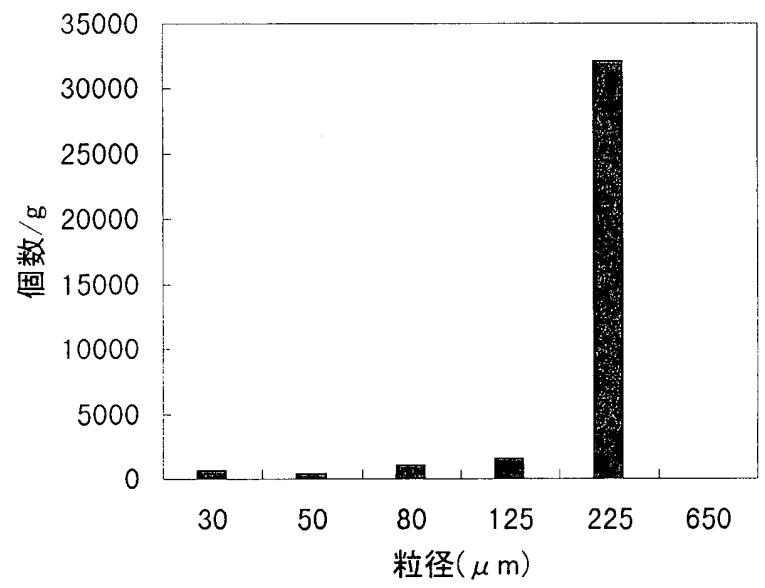

図 10 細骨材（豊浦標準砂）の粒度分布

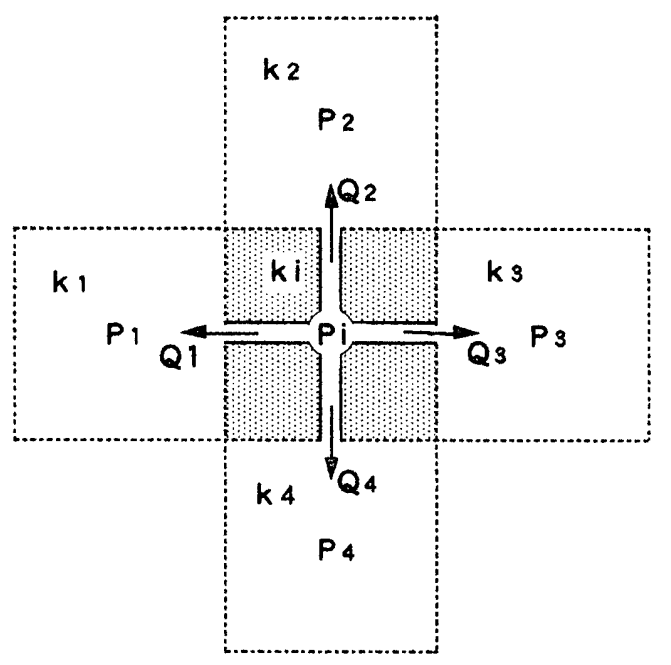

図 11 i 接点とその周りの接点領域 


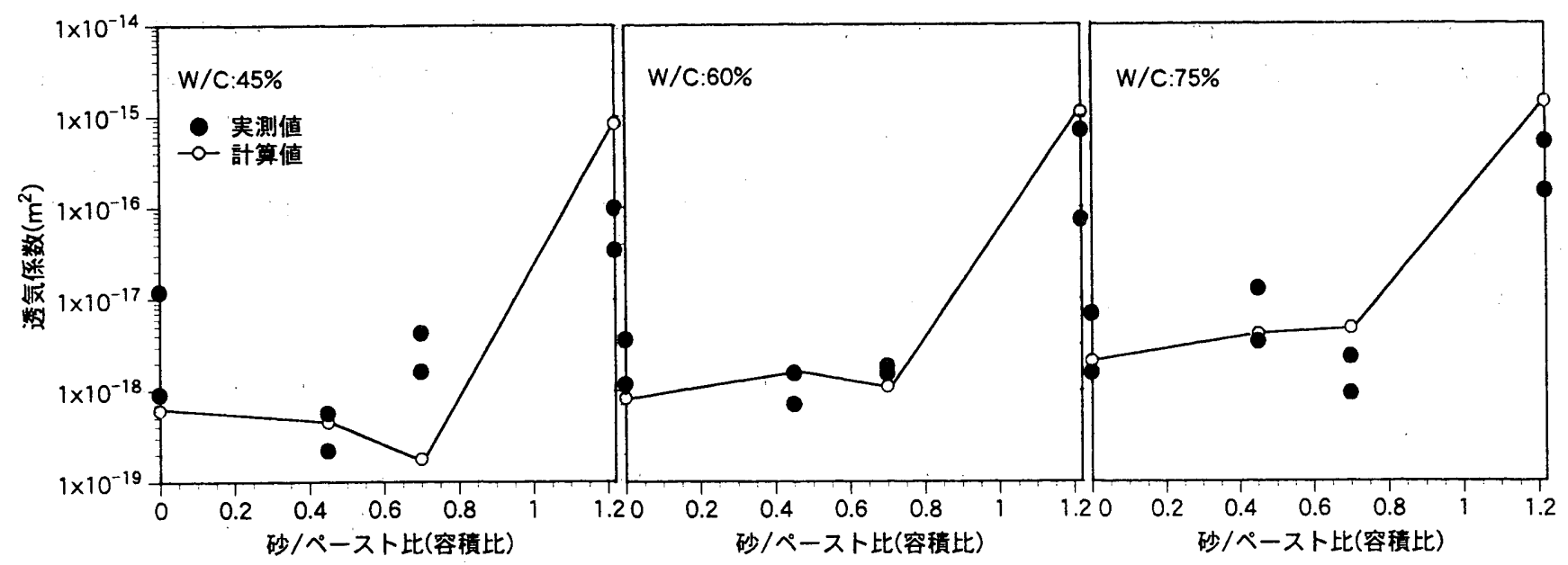

図 12 モルタルの透気係数の测定值と計算值

を表す。

(5)この関保はすべての接点について成立することから、接点数分の 連立一次方程式が得られる。

(6)連立方程式を解き、各接点の圧力 $\mathrm{P}(\mathrm{i})$ を求める。

(7)求められた圧力 $\mathrm{P}(\mathrm{i})$ と透気係数 $\mathrm{k}(\mathrm{i})$ から、流入面から流出面方向 に垂直な断面の流れについて総和を計算し、モデル全体の流量を求 める。

(8)流量からモデルの透気保数を求める。

\section{(4) 計算結果およひ考察}

図 12 亿標準砂モルタルの透気倸数の測定值と計算値を示寸。セ メントペースト単味の状態から細骨材が增加してゆく初期の段階で は、透気性はほとんど增加せず、試験体によっては逆に低下するも のもある。しかしさらに細骨材量が増加すると、特に細骨材量の多 い領域での透気性が急激に增加する。

当初の細骨材量の增加が必ずしも透気性を增加させなかったの は、ほとんじ透気しない細骨材量の增加により、透気の期待される セメントペースト量の減少によるためと考えられる。また、骨材量 のある程度の量からの透気性の急激な增加は、きわめて透気のしや すい、骨材とペースト界面近傍の細孔構造の粗な領域の增加、およ びそれらの領域がつながり、連続する頻度が多くなるためと推定さ れる。

ここで得られた計算結果は、実験値と完全に一致するものではな いが、その傾向をよく再見していると思われる。

\section{5 結論}

セメントモルタルの透気性に及ぼす細骨材量の影響について検討 した、本論文で得られた結論は以下のとおりである。

（1）細骨材量は透気性に強い影響を与える。すなわち砂量の少な い領城では、多少の砂量の増加は透気性をほとんど変化させないか、 もしくは低下させる。砂量の多い領域では透気性を急激に增加させ る。

（2）稩骨材量の透気性に及ぼす影響は、ペースト容積と細骨材容 糟との割合を変化させること、および、細骨材とペースト界面近傍 の組織が粗である領域の容積を変化させることに起因すると考えら れる。

（３）細骨材、ペースト、その界面より構成されるモデルを用いた
解析により、モルタルの砂量の透気性に及ぼす影響をある程度定量 的に評価できることを示した。

碀辞

本研究を実施するにあたり、北海道大学、名和豊春先生、秩父小 野田セメント（株）、羽原俊祐氏の討論および実験上の協力を得ま した。心より感謝申しあげます。

\section{参考文觔}

1) K.L.Scrivener and P.L.Pratt:Characterisation of interfacial microstructure; RILEM REPORT 11 - Interfacial Transition Zone in Concrete, E\&FN SPON, pp.3-17, 1996

2）菅谷秀幸：骨材一セメントペースト界面；セメント・コンクリー 卜.No.567, pp.46-48, 1994

3）田中㤐二、端 直人、橋田 浩 : 水分を含む状態でのセメントモ ルタルの透気性：日本建築学会構造系論文報告集、第 469 号, pp.9-15, 1995

4) B.K.Nyame: Permeability of normal and lightweight mortars; Magazine of Concrete Research, Vol.37, No.130, pp.44-48, 1985

5) J.P.Ollivier and M.Massat: The effect of the transition zone on transfer properties of concrete; RILEM REPORT 11 Internal Transition Zone in Concrete, E\&FN SPON, pp.117-131,1996

6) Y.H.Houst, H.Sadouki and F.H.Wittman: Influence of Aggregate Concentration on the Diffusion of $\mathrm{CO}$ and $\mathrm{O}$ Interfaces in Cementitious Composites, RILEM, E\&FN SPON, pp. $279-288$,

7) R.K.Dhir, P.C.Hewlett and Y.N.Chan: Near surface characteristics of concrete, Intrinsic permeability; Magazine of Concrete Research, Vol.41, No.147, pp.87-97, 1989

8）田中享二、端 直人、橋田 浩 : 若材齢モルタルの乾燥途中にお ける細孔構造と水分状態; 日本建築学会構造系論文報告集、第 460 号, pp.11-18, 1994

9) P.Kumer Metha: CONCRETE-Structure, Properties and Materilas; PRETICE-HALL, pp.26-27, 1986

10) F.A.L.Dullien: Porous Media-Fluid Transport and Pore Structure; Academic Press.Inc., 1992

11）内川 浩、羽原俊祐、沢木大介 : 硬化モルタル及びコンクリ 一ト中の遷移帯厚さと強度との関媇の検討.; コンクリート工学 論文集、Vol.4, No.2, pp.1-8, 1993

12）星野昌幸、苫米地 司：微視的観察にもとづくセメントペー ス卜と骨材の界面の形成過程と強度：材料，Vo.135，No.355, pp.12-18, 1983

13) J.Grandent and P.Olliveier:Orientation of Hydration Products near Aggregate Surface; Proc.7th International Congress on the Chemistry of Cement,Vol.3, pp.63-68, 1980 